\title{
Additional Notes upon the Angiosperms Tetracentron, Trochodendron, and Drimys, in which Vessels are absent from the Wood.
}

BY

\author{
I. W. BAILEY,
}

Bussey Institution,

AND

\section{W. P. THOMPSON, \\ University of Saskatchewan.}

With Plate XVI and nine Figures in the Text.

$\mathrm{N}$ a paper read at the celebration of the twentieth anniversary of the 1 New York Botanical Garden, September I9I 5, the writers (11) discussed the significance of certain features in the anatomy of Tetracentron, Trochodendron, and Drimys. It was shown that not only are true vessels entirely absent from the normal wood of the stem of these genera, but also from those organs or regions ${ }^{1}$ that are considered by certain morphologists to be retentive of ancestral characters.

The accuracy of the conclusions reached by the writers in regard to the absence of vessels in Tetracentron, Trochodendron, and Drimys has been brought into question by the work of Jeffrey and Cole (6). These investigators claim to have found vessel-like structures in injured roots of Drimys colorata, which abnormalities are considered to indicate that the ancestors of Drimys, Trochodendron, and Tetracentron possessed true vessels.

However, it is admitted by Jeffrey and Cole that the elements, described and figured by them, lack the perforations of normal vessels. In view of this fact, it is desirable to determine to what extent these traumatically produced cells are really vessel-like in structure.

The word vessel, which was used in a variety of meanings by the older phytotomists, was first clearly defined by von Mohl (8) in the middle of the last century.

' The primary form of the elementary organs of plants is that of a completely closed, globular or elongated vesicle, composed of a solid membrane.

\footnotetext{
1 Root, leaf, node, floral axis, seedling, first annual ring, \&c.
}

[Annals of Botany, Vo1. XXXII. No. CXXVIII. October, rgr8.] 
and containing a fluid. If this remains still closed after its development is completed, it is called a cell, cellula, but if a row of utricles arranged in a line become combined, during development, into a tube with an uninterrupted cavity, through the absorption of their cross walls, a compound elementary organ is produced-the vessel (spiroid of Link).'

The importance of von Mohl's developmental studies was appreciated by many of his contemporaries, and his distinction between vessels, compound structures, and simple tracheary cells has been accepted, in but slightly modified form, by subsequent writers, including Caspary, Sanio, de Bary, Sachs, Strasburger, Van Tieghem, Scott, and Coulter.

Thus, in its generally accepted modern meaning, a vessel, Gefäss, trachea (Sanio), is a compound structure that arises from a series of cells by the loss of the pit membranes in the division walls between the members of the series, the latter being termed the members or segments of the vessel. ${ }^{1}$

The traumatically produced structures, described and figured by Jeffrey and Cole, are not compound structures, but simple cells, having pits with membranes and well-developed bordering areas (Pl. XVI, Fig. 9). Therefore they are not vessel-like in structure.

The next question to be considered is, are these tracheary cells segments of vestigial vessels? If they are to be considered as such, there must be some criterion for distinguishing them from ordinary tracheary elements. In macerations of the secondary wood of plants which possess vessels, it is possible to separate the segments of the vessels from tracheides, fibre-tracheides, and libriform fibres by their size, form, or the structure of their pitted walls. Thus, in the majority of the Dicotyledons, the vesselsegments are not only noticeably larger in diameter than the neighbouring tracheary elements, but show unmistakable evidences of having been joined together to form a segmented tube or ' duct' (Text-figs. 6-9). Even in those exceptional cases where the segments of the vessels resemble the surrounding tracheary cells in general size and shape, they can readily be distinguished from them by the structural peculiarities of certain of their pits, which are perforated and without well-developed bordering areas.

The cells which occur in the root of Drimys resemble the surrounding tracheides in general size and shape, and are quite unlike the typical vesselmembers of Euptelea, Illicium, Kadsura, Schizandra, Michelia, Magnolia, Talauma, and Liriodendron (Text-figs. I-9). Furthermore, these traumatically produced elements possess throughout pits with well-developed bordering areas and membranes, which serve to separate them quite sharply from the vessel-segments of the genera just enumerated.

Jeffrey and Cole placed much emphasis upon the fact that elongated

1 To refer to a single cell as a vessel, as has been done by Jeffrey and Cole throughout their paper, appears to be somewhat unfortunate, and likely to lead to unnecessary confusion. 
Angiosperms Tetracentron, Trochodendron, and Drimys. 505

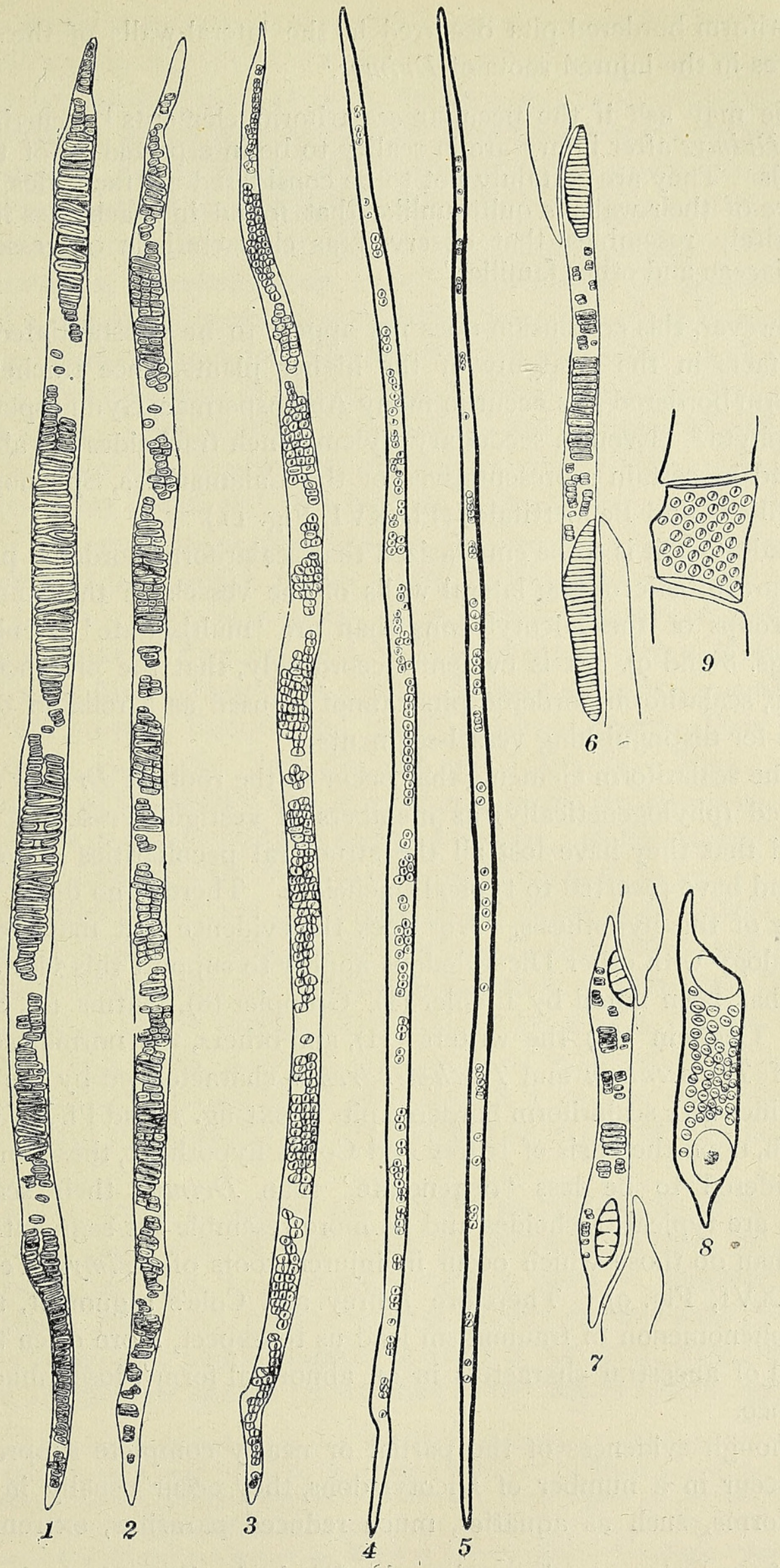

TexT-FIGS. I-5. Types of tracheides that occur in the secondary xylem of Tetracentron, Trochodendron, and Drimys. 6. Type of vessel-segment that occurs in the secondary xylem of Cercidiphyllum, Euptelea, and various Monimiaceae. 7. Type of vessel-segment that occurs in the secondary xylem of the Magnolieae. 8. Type of vessel-segment that occurs in the secondary xylem of the Lauraceae and many other Dicotyledons. 9. Type of vessel-segment that occurs in the secondary xylem of the Leguminosae and many other Dicotyledons. 
or scalariform bordered pits occurred in the lateral walls of the tracheary structures in the injured roots of Drimys.

'We may ask if the peculiar scalariform elements ${ }^{1}$ occurring in the root of Drimy's after injury are in reality to be interpreted as of the nature of vessels. They are certainly not to be considered as tracheides, since the sculpture of their walls is quite unlike that found in tracheides in general, and entirely resembles that observed as characteristic of vessels in the Magnoliaceae and other families.'

However, this conclusion does not appear to be substantiated by wellknown facts in the anatomy of the higher plants, since tracheides with scalariform bordered pits occur in many Angiospermae, Gymnospermae, and Pteridophyta. ${ }^{2}$ Even in secondary xylems, such tracheides are abundantly developed in certain representatives of the Calamariales, Sphenophyllales, Cycadofilices, and Bennettitales (Pl. XVI, Fig. II).

In addition, it is to be emphasized that scalariform bordered pits are no more characteristic of the lateral walls of the vessels in the Ranales and other groups of the Dicotyledons than are 'multiseriate' circular types (Text-figs. 8 and 9). It is evident, accordingly, that the presence of nonperforate, scalariform bordered pits cannot be used as a reliable diagnostic criterion for distinguishing vessel-segments.

If the scalariform elements that occur in the roots of Drimys are to be considered (phylogenetically) as members of vestigial vessels, it must be admitted that they have lost all the structural peculiarities of vessel-segments and have reverted to typical tracheides. There is no direct evidence in favour of this hypothesis. Nor does the evidence that may be derived from analogy with other Dicotyledons appear to support this view.

As has been noted by Eichler (1), Groppler (3), Harms (4), Solereder (9), Van Tieghem (12), the writers (11), and others, the normal secondary xylem of Tetracentron and Trochodendron is characterized by the presence of tracheides with scalariform bordered pits (Text-fig. I, and P1. XVI, Fig. 6). Although, upon the basis of Jeffrey and Cole's hypothesis, these forms must be considered to be less 'degenerate' than Drimys, their scalariform elements are typical tracheides and no more resemble the segments of true vessels than do those which occur in injured roots of Drimys (Text-fig. 2, and Pl. XVI, Fig. 9). Therefore Jeffrey and Cole's argument, that 'the general phenomenon of traumatism lead us to expect, more often than not, the recall of ancestral characters in an abnormal form', loses much of its significance.

Although evidences of the partial or nearly complete suppression of vessels occur in a number of Dicotyledons, they occur usually in unusual growth forms, such as aquatics, much reduced parasites, extreme xero-

${ }^{1}$ Referring to elements of the secondary xylem with closed scalariform bordered pits.

2 The terminology of Engler and Gilg is used in this paper. 
phytes, \&c., where there are obvious physiological reasons for the degeneration of tracheary tissue. Furthermore, it is a notable fact that, even among such highly specialized plants as these, the complete suppression of vessels does not occur in plants having well-developed secondary xylem in their roots and stems. Poorly developed or vestigial vessels, easily recognized as such by their structural peculiarities, are present in some part of the plant.

However, there does not appear to be any reliable evidence to indicate that Tetracentron, Trochodendron, and Drimys should be placed in this category of specialized Dicotyledons. According to E. H. Wilson (14), the well-known botanical explorer, Tetracentron sinense, Oliv., is the second largest Dicotyledonous tree in the montane forests of central and western China. It attains a height of $16-30 \mathrm{~m}$. and a stem circumference of 4-6 m., and has a large crown covered with leaves of extremely herbaceous texture. It grows on moist slopes and rich bottom lands in the neighbourhood of streams. Trochodendron aralioides, Sieb. et Zucc., like Tetracentron, is a large arborescent form which attains a height of $25 \mathrm{~m}$. and a stem circumference of $3-8 \mathrm{~m}$. It grows in moist, warm, montane forests of central and southern Japan and of Formosa, and has a large crown with well-developed foliage. Unlike these monotypic genera, Drimys comprises a number of species which grow in Central and South America, Borneo, New Guinea, New Caledonia, Australia, New Zealand, and Tasmania. They are small trees or shrubs which usually live in relatively moist environments. Their leaves, which vary considerably in size and texture, are not unlike those of many Dicotyledons of moist tropical or warm temperate forests.

In other words, there are no obvious physiological or ecological reasons for the degeneration of vessels in Tetracentron, Trochodendron, and Drimys. From analogy with the structure of other arborescent and fruticose Dicotyledons, it appears to be highly improbable that such a growth form as Tetracentron, with its large crown, thin leaves of herbaceous texture, and relatively high rate of transpiration, should once have possessed vessels and subsequently lost them, as has been considered to be the case by: Groom (2) and Jeffrey and Cole.

It has been stated by Jeffrey (5) that the so-called laws of recapitulation, reversion, and retention are either of universal validity or of little scientific value, and that they cannot in certain cases be admitted and in others denied. Assuming, for the sake of argument, that such 'laws' can actually be formulated and universally applied in the study of plant evolution, ${ }^{1}$ what significance should be attached to the occurrence of scalariform

1 It should be noted in this connexion that, even if certain organs of plants are inherently more conservative than others, it must frequently be extremely difficult to determine, in the absence of reliable collateral evidence, whether a given structure in a given region is cenogenetic or truly palingenetic; for even the most ardent advocates of the doctrines of recapitulation, reversion, and retention, who tend to minimize or ignore the effects of physiological and ecological factors, admit that cenogenetic characters do occur in roots, seedlings, traumatic tissue, \&c. 
tracheides in injured roots and first annual rings of stems of Drimys? Obviously, these traumatically produced elements might logically be considered to indicate that the ancestors of the existing species of Drimys possessed tracheides with scalariform bordered pits, such as occur in the normal secondary xylem of Tetracentron and Trochodendron (PI. XVI, Fig. 6), and were present in that of a number of Mesozoic and Palaeozoic plants (Fig. II).

However, it was appreciated by Jeffrey and Cole that their interpretation of the phenomena in injured roots of Drimys-as traumatic recapitulations of ancestral structures in a very 'conservative ' organ-would lose much of its significance if scalariform elements occurred in the secondary xylem of stems and in uninjured roots. Therefore, much emphasis was placed upon the fact that scalariform tracheary pitting does not occur in stems and uninjured roots except in the immediate vicinity of the primary xylem.

Recently the writers have examined a considerable amount of material of various species of Drimys. This material included stems and roots of plants grown in their native habitats in South America and Australasia, and plants grown in nurseries and greenhouses in England and the United States. As is shown in Plate XVI, the tracheides were found to vary considerably in size and in the thickness of their secondary walls. In certain specimens (Figs. I and 5), growth layers or concentric rings were clearly differentiated; whereas in others there were only slight indications of zonation (Figs. 2, 3, and 4). In the stems of D. Winteri, Forst., secured from small plants grown in greenhouses, and in stems of $D$. colorata, Raoul, and D. axillaris, Forst., from New Zealand, the tracheides were provided with one or two rows of circular bordered pits in their radial facets (Text-fig. 4, and Pl. XVI, Fig. 8). On the other hand, in stems of $D$. Winteri from Chile and in roots of $D$.colorata and $D$. axillaris from New Zealand, the larger tracheides tended to have several rows of bordered pits in their radial walls (Text-fig. 3, and PI. XVI, Fig. 7). Scalariform pits were of more or less frequent occurrence in many of these tracheides (Pl. XVI, Fig. I2). They occurred in normal uninjured stems and roots, and in the later as well as the earlier formed portions of the xylem. In young stems -showing 5-15 growth layers-of $D$. Winteri from South America, the secondary xylem not infrequently resembled that which occurs in Tetracentron. Gròwth layers were clearly differentiated (Pl. XVI, Fig. 5). The larger, first-formed tracheides in these concentric rings were typical scalariform, whereas the smaller terminal tracheides possessed circular bordered pits (Pl. XVI, Fig. IO). Transitional types of pitting occurred in intermediate tracheides. In other words, the layers of scalariform tracheides, as in Tetracentron, were separated by zones of non-scalariform tracheary elements.

It is evident, accordingly, that scalariform pits may occur in the normal 
secondary xylem of uninjured stems and roots of Drimys. Furthermore, the occurrence and distribution of these structures appears to be influenced, to some extent at least, by purely physiological and ecological factors. Since the occurrence of tracheides with scalariform bordered pits cannot be explained satisfactorily upon the assumption that Tetracentron, Trochodendron, and Drimys are 'evascularized' Dicotyledons-'degenerate' forms whose ancestors possessed true vessels in their secondary xylem-what is the probable significance of these interesting tracheary structures?

From the morphological and phylogenetic points of view, it may be assumed that (I) Tetracentron, Trochodendron, and Drimys are descended directly from ancestors which possessed scalariform tracheides in their secondary xylem, or (2) they are descended from ancestors having tracheides with circular bordered pits. If the latter hypothesis be accepted, the scalariform tracheides in the secondary xylem of Tetracentron, Trochodendron, and Drimys must have been acquired de novo, e.g. by the horizontal elongation of single circular bordered pits, by the fusion of rows of circular pits, or by a transfer of the impulse to form scalariform pits from the primary to the secondary meristem-homoeosis, Leavitt (7).

In this connexion it is desirable to discuss in greater detail the types of tracheary pitting that occur in Tetracentron, Trochodendron, and Drimys. The secondary xylem in the first two genera is characterized by possessing clearly differentiated growth layers or annual rings (Pl. XVI, Fig. I). The tracheides in the first-formed portion of the concentric layers are comparatively large and thin-walled and have numerous scalariform bordered pits in the radial facets (Text-fig. 1, and Pl. XVI, Fig. 6) ; those in the lastformed portion of the rings are small, thick-walled, and fibre-like, and have scattered circular bordered pits (Text-fig. 5, and Pl. XVI, Fig. 6). Between the typical scalariform and fibre-like elements, intermediate types of tracheides with transitional types of pitting occur. These cells show all gradations between scalariform and circular bordered pits. In certain cases the scalariform bordered pits are replaced by two or more smaller pits (Text-fig. 2) ; in others, by single oval or circular pits (Pl. XVI, Fig. 6). When the former phenomenon occurs, the circular bordered pits form horizontal and vertical rows, so-called 'opposite' pitting. This type of pitting may grade into the type which occurs in the fibre-like tracheides, by a simple process of reducing the number of vertical rows to one, and by a gradual decrease in the number of pits in the remaining row. Occasionally, the vertical rows become more or less 'staggered', producing the so-called 'alternating' type of pitting. In the genus Drimys the secondary xylem may be composed of similar combinations of tracheary elements or of one or more of the intermediate or transitional types (Pl. XVI, Figs. 7, 8, 9, 10, and 12 ).

In so far as the transitional types of pitting, which occur in the secondary L 12 
xylem of Tetracentron, Trochodendron, Drimy's, and other genera of the Ranales, are concerned, it is just as reasonable to interpret them as indicating that circular bordered pits are derived from scalariform bordered pits as vice versa. Indeed, if one considers that the laws of recapitulation, reversion, and retention cannot in certain cases be admitted and in others denied, the more abundantly developed scalariform pitting in young stems of $D$. Winteri and injured roots of $D$. colorata should be interpreted as indicating that Tetracentron, Trochodendron, and the various species of Drimys form a graded series, illustrating the replacement of scalariform by circular bordered pits. Therefore, in the absence of reliable evidence which might be considered to prove that the secondary tracheides of the Coniferae or similar forms have been or can be modified to form typical scalariform secondary tracheides, the possibility that the vessel-less Tetracentron, Trochodendron, and Drimys are descended directly from ancestors having tracheides with scalariform bordered pits deserves careful consideration in discussions concerning the origin of the Angiosperms.

It is to be emphasized that, although the secondary xylem of Tetracentron and Trochodendron is in general unlike that of the Coniferae or higher Gymnosperms, it resembles the wood of certain Palaeozoic and Mesozoic plants, e.g. Calamites, Protopitys, ${ }^{1}$ figured by Solms-Laubach (10), and certain Cycadeoideae described by Wieland (13). In all of these plants, as well as in the primary xylem of many ferns, there are transitions between typical scalariform bordered pitting and 'opposite', 'alternate', or uniseriate circular bordered pitting. Recently, one of the writers enjoyed the privilege of studying and photographing Dr. Wieland's excellent slides of type material of Cycadeoidea Dartoni (Coulter and Chamberlain), Wiel. As is shown in Pl. XVI, there is a striking similarity between the tracheary pitting of this fossil and that of Tetracentron and Trochodendron. The writers emphasize this similarity in tracheary structure, not as indicating necessarily close genetic relationship between the Ranales and Bennettitales, but in order to show that certain of the Pteridophyta and older Gymnospermae possessed a more plastic and generalized type of pitting than that of the relatively stereotyped Coniferae.

\section{Conclusions.}

The scalariform tracheary elements that occur in injured roots of Drimys colorata are not vessel-like in structure.

They are typical tracheides having transitional types of pitting, such as occur in many Pteridophyta, Gymnospermae, and Angiospermae.

They occur in uninjured stems and roots of Tetracentron, Trochodendron, and Drimys, as well as in traumatic tissue.

True vessels do not occur in the xylem of these genera.

1 This genus is now placed in the Cycadofilices. 
Not only is there no direct structural evidence which might be considered to indicate that these vessel-less Angiosperms are 'evascularized' forms, but there appears to be no physiological or ecological evidence for supposing that they are 'degenerate' Dicotyledons whose ancestors possessed true vessels in their secondary wood.

The secondary xylem of Tetracentron and Trochodendron, which is entirely unlike the wood of the Coniferae, closely resembles that of certain of the Pteridophyta and older Gymnospermae.

In conclusion, the writers wish to thank their botanical colleagues in Australasia, South America, England, and Japan for their courtesy in sending valuable material of Drimys, Tetracentron, and Trochodendron. To Dr. G. R. Wieland and Dr. E. W. Berry the writers are indebted for the opportunity of studying and photographing sections of Palaeozoic and Mesozoic plants.

\section{LITERATURE CITED,}

1. Eichler, A. W.: Bemerkungen uiber die Structur des Holzes von Drimys und Trochodendron, sowie über die systematische Stellung der letzteren Gattung. Flora, N.F., xxii, 1864, pp. $449^{-} 5^{8}$.

2. Groom, P.: Remarks on the Ecology of Coniferae. Ann. Bot., xxiv, I9Io, pp. 24I-69.

3. Groppler, R. : Vergleichende Anatomië des Holzes der Magnoliaceen. Bibliotheca Bot., vi, I 894, pp. I-49.

4. Harms, H.: Ueber die Stellung der Gattung Tetracentron Oliv, und die Familie der Trochodendraceen. Ber. Deut. Bot. Ges., xv, 1897, pp. 350-60.

5. Jeffrey, E. C.: The History, Comparative Anatomy, and Evolution of the Araucarioxylon Type. Proc. Amer. Acad. Arts and Sci., xlviii, I9 I 2, pp. 53I-7I.

6. Jefrerey, E. C., and Cole, R. D.: Experimental Investigations on the Genus Drimys. Ann. Bot., $\mathrm{xxx}, \mathrm{19}$ 16, pp. 359-68.

7. Leaviti, R. G.: A Vegetative Mutant, and the Principles of Homoeosis in Plants. Bot. Gaz., xlvii, 1909, pp. 30-68.

8. MoнL, H. von : Grundziige der Anatomie und Physiologie der vegetabilischen Zelle. Braunschweig, I 85 I.

9. Solereder, H.: Systematische Anatomie der Dicotyledonen. Stuttgart, I899.

10. Solms-Laubach, H., Graf ZU: Ueber die in den Kalksteinen des Kulm von GlätzischFalkenberg in Schlesien enthaltenen Structur-bietenden Pflanzenreste. Bot. Zeit., li, I893, pp. $197^{-210}$.

11. Thompson, W. P., and BAILey, I. W.: Are Tetracentron, Trochodendron, and Drimys Specialized or Primitive Types? Mem. N. Y. Bot. Garden, vi, I916, pp. 27-32.

12. Tieghem, Ph. Van : Sur les Dicotylédones du groupe des Homoxylées. Jour. Bot. (Paris), xiv, I900, pp. 259, 330.

13. Wieland, G. R. : American Fossil Cycads, II. Washington, I9I6.

14. Wilson, E. H., ex Sargent, C. S. : Plantae Wilsonianae, i, pp. 4I7-I8. Cambridge, r9i3. 
5 I 2 Bailey and Thompson.-Notes upon the Angiosperms.

\section{DESCRIPTION OF PLATE XVI.}

Illustrating Messrs. Bailey and Thompson's paper on the Angiosperms Tetracentron, Trochodendron, and Drimys.

Fig. I. Trochodendron aralioides. Transverse section of the secondary xylem, showing growth layers. $\times 90$.

Fig. 2. Drimys colorata. Transverse section of the secondary xylem of a stem. $\times 90$.

Fig. 3. Drimys colorata. Transverse section of the secondary xylem of a root, showing poorly differentiated growth layers. $\times 90$.

Fig. 4. Drimys Winteri. Transverse section of the secondary xylem of a mature stem, showing poorly differentiated growth layers. $\times 90$.

Fig. 5. Drimys Winteri. Transverse section of the secondary xylem of a young stem, showing second, third, and fourth growth layers. $\times 9{ }^{\circ}$.

Fig. 6. Trochodendron aralioides. Radial longitudinal section of the secondary xylem. $\times 90$.

Fig. 7. Drimys colorata. Radial longitudinal section of the secondary xylem, illustrating a type of pitting that occurs in the stems and roots of many specimens of Drimys. $\quad \times 90$.

Fig. 8. Drimys colorata. Radial longitndinal section of the secondary xylem, illustrating a type of pitting that occurs in the stems and roots of certain specimens of Drimys. $\times 90$.

Fig. 9. Drimys colorata. Radial longitudinal section of the secondary xylem of an injured root,

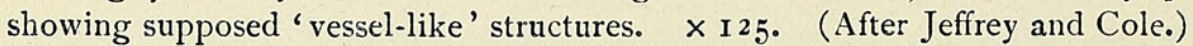

Fig. 10. Drimys Winteri. Radial longitudinal section of the secondary xylem of a young stem, showing (left) last-formed tracheides of third growth ring and (right) first-formed scalariform tracheides of fourth growth layer. $\times 270$.

Fig. II. Cycadeoidea Dartoni. Radial longitudinal section of the secondary xylem, showing scalariform and transitional types of bordered pitting. $\times 100$.

Fig. I2. Drimys Winteri. Radial longitudinal section of the secondary xylem, showing circular and scalariform bordered pits, such as occur in uninjured stems and roots of many specimens of Drimys. $\times 260$. 
Annals of Botany,

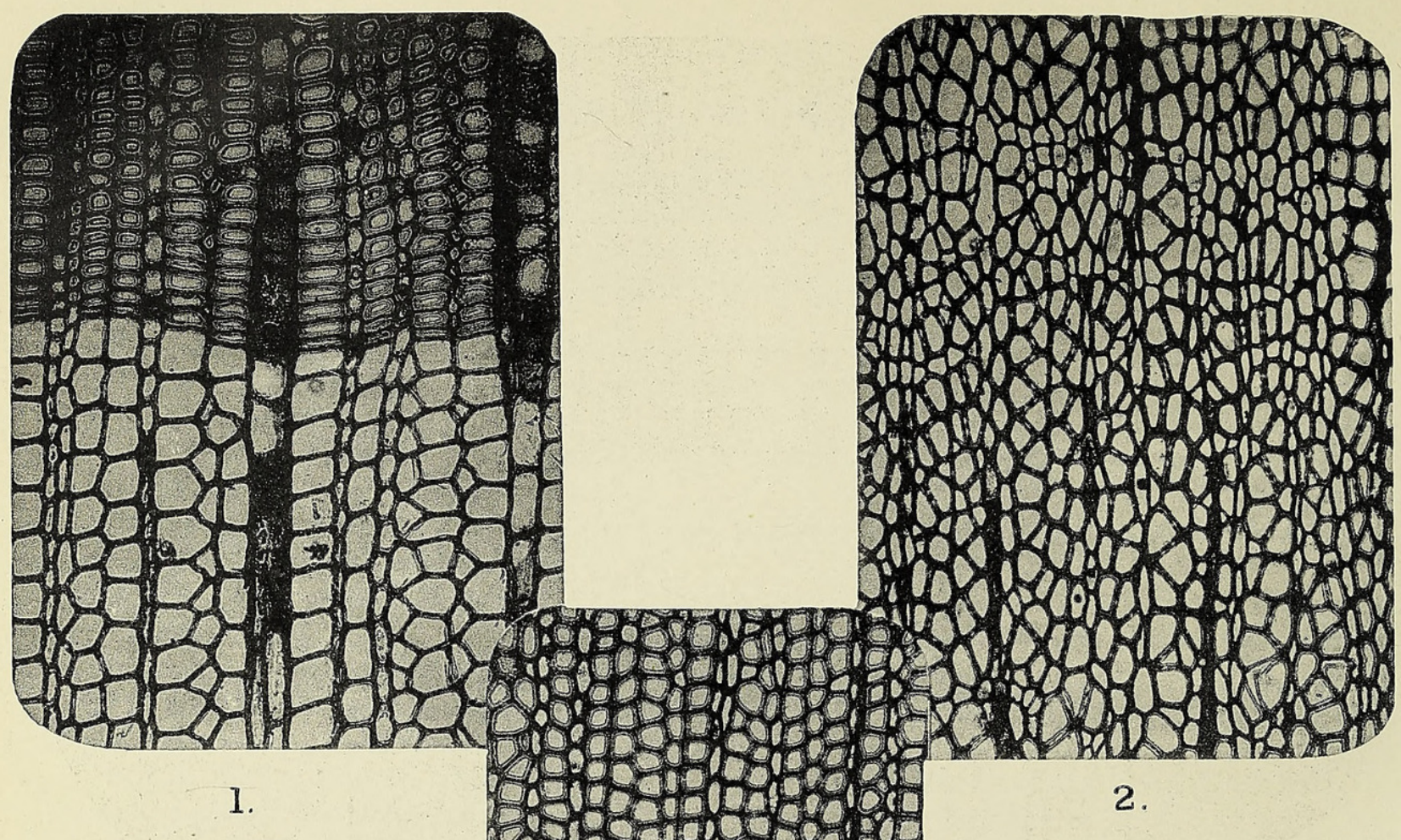

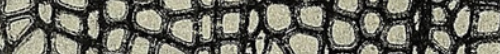

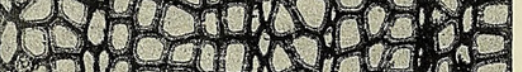

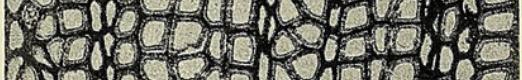

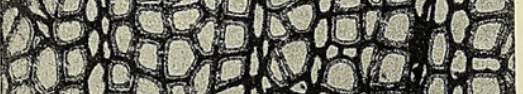

1.4. H

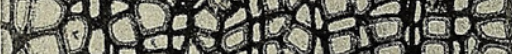

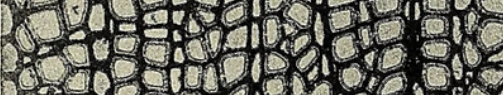

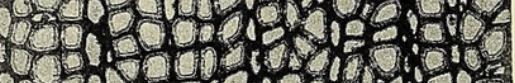

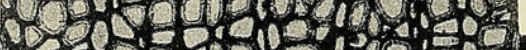

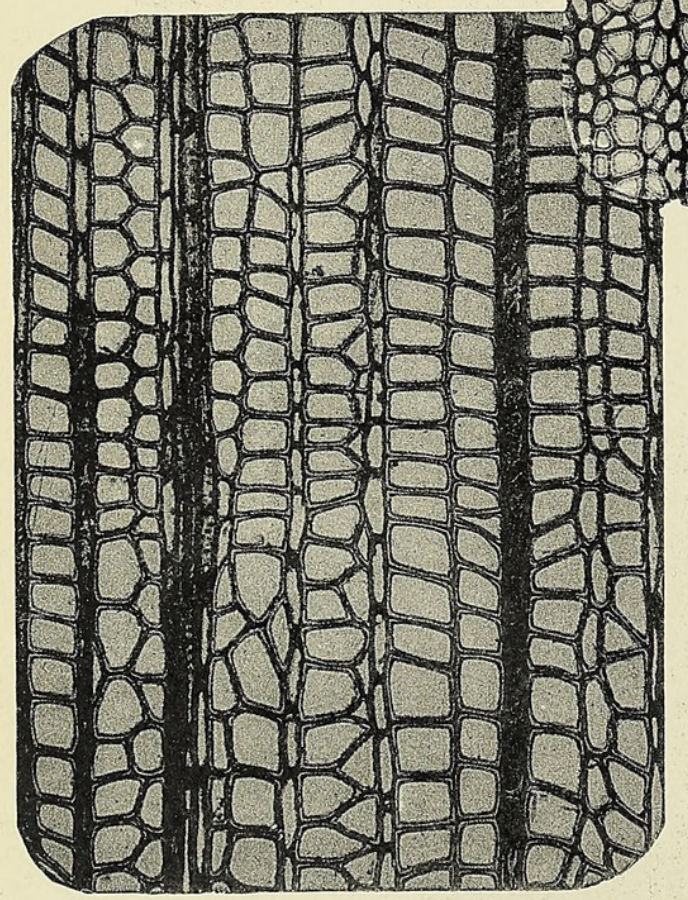

4
3.

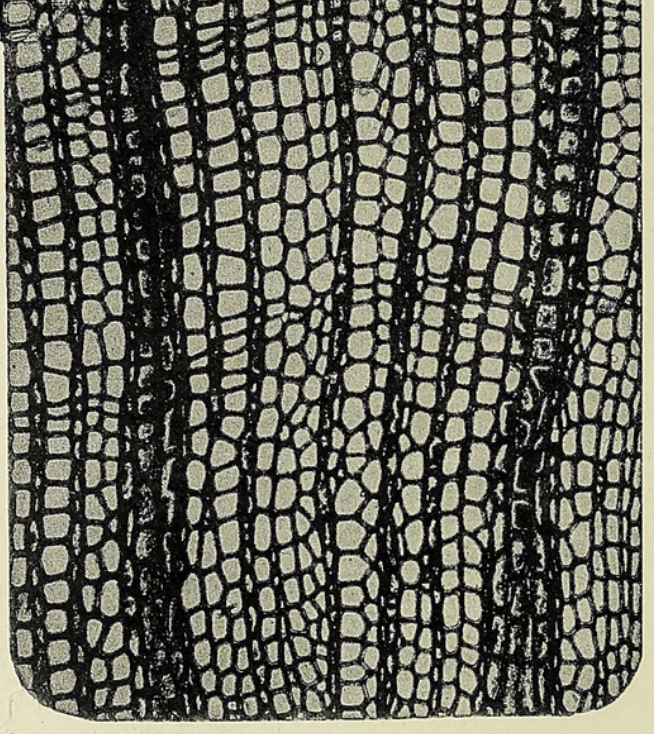

5.

BAILEY \& THOMPSON - TROCHODENDRON, TETRACENTRON \& DRIMYS. 
Vol. XXXII, Pl. XVI.

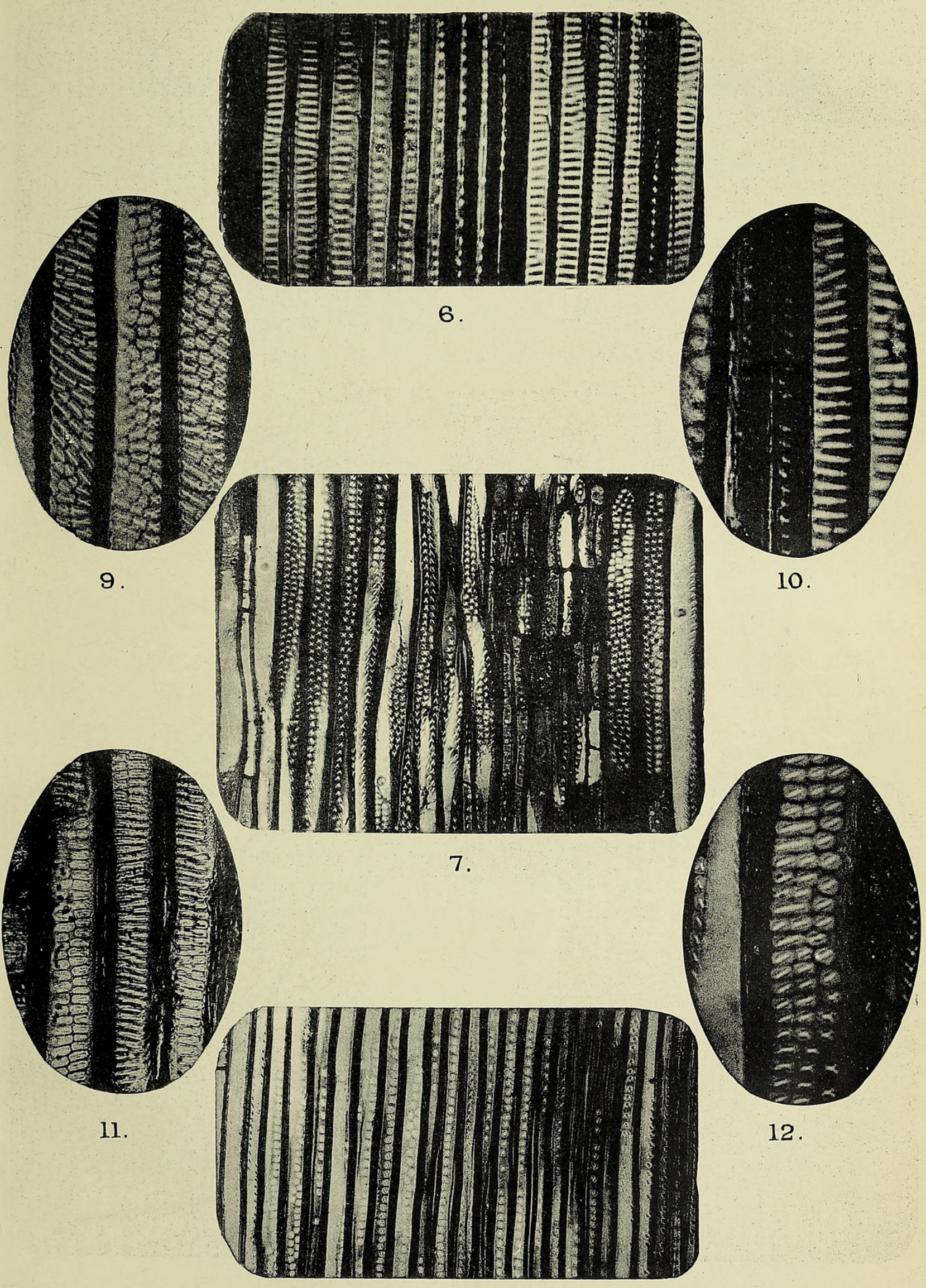

8. 


\section{$2 \mathrm{BHL}$ Biodiversity Heritage Library}

Bailey, Irving W. and Thompson, W. P. 1918. "Additional notes upon the angiosperms Tetracentron, Trochodendron, and Drimys, in which vessels are absent from the wood." Annals of botany 32, 503-512.

https://doi.org/10.1093/oxfordjournals.aob.a089688.

View This Item Online: https://www.biodiversitylibrary.org/item/238284

DOI: https://doi.org/10.1093/oxfordjournals.aob.a089688

Permalink: https://www.biodiversitylibrary.org/partpdf/320230

\section{Holding Institution}

Smithsonian Libraries

\section{Sponsored by}

Biodiversity Heritage Library

\section{Copyright \& Reuse}

Copyright Status: Not in copyright. The BHL knows of no copyright restrictions on this item.

This document was created from content at the Biodiversity Heritage Library, the world's largest open access digital library for biodiversity literature and archives. Visit BHL at https://www.biodiversitylibrary.org. 